\title{
The Formation of Garnet in Olivine-Bearing Metagabbros from the Adirondacks
}

\author{
Craig A. Johnson ${ }^{1}$ and Eric J. Essene \\ Department of Geological Sciences, The University of Michigan, Ann Arbor, Michigan 48109, USA
}

\begin{abstract}
A regional study of olivine-bearing metagabbros in the Adirondacks has permitted testing of the $\mathbf{P}$ (pressure)- $\mathrm{T}$ (temperature) $-\mathrm{X}$ (composition) dependence of garnet-forming reactions as well as providing additional regional metamorphic pressure data. Six phases, olivine, orthopyroxene, clinopyroxene, garnet, plagioclase and spinel, which can be related by the reactions:

orthopyroxene + clinopyroxene + spinel

+ anorthite $=$ garnet, and

forsterite + anorthite $=$ garnet

occur together both in coronal and in equant textures indicative of equilibrium. Compositions of the respective minerals are typically $\mathrm{Fo}_{25-72}, \mathrm{En}_{44-75}, \mathrm{En}_{30-44} \mathrm{Fs}_{9-23} \mathrm{Wo}_{47-49}$, $\mathrm{Pp}_{13-42} \mathrm{Alm}_{39-63} \mathrm{Gr}_{16-20}, \mathrm{An}_{29-49}$ and $\mathrm{Sp}_{16}{ }_{58}$. When they occur in the same rock, equant and coronal garnets are homogeneous and compositionally identical suggesting that chemical equilibrium may have been attained despite coronal textures. Extrapolating reactions in the simple $\mathrm{CMAS}^{2}$ system to granulite temperatures and making thermodynamic corrections for solid solutions gives equilibration pressures (using the thermometry of Bohlen et al. 1980b) ranging from about $6.5 \mathrm{~kb}$ in the Lowlands and southern Adirondacks to $7.0-8.0 \mathrm{~kb}$ in the Highlands for the assemblage olivine-plagioclase-garnet. These results are consistent with inferred peak metamorphic conditions in the Adirondacks (Valley and Bohlen 1979; Bohlen and Boettcher 1981). Thus the isobaric retrograde path suggested by Whitney and McLelland (1973) and Whitney (1978) for the formation of coronal garnet in olivine melagabbros may not be required. Application of the same equilibria gives $>8.7 \mathrm{~kb}$ for South Harris, Scotland and $0.9 \mathrm{~kb}$ for the Nain Complex. Disagreement of the latter value with orthopyroxeneolivine-quartz barometry (Bohlen and Boettcher 1981) suggests that the use of iron-rich rocks (olivines $\geqq \mathrm{Fa}_{50}$ ) results in errors in calculated pressures.
\end{abstract}

\section{Introduction}

Garnet has classically been recognized as a high $P$ phase in metamorphosed igneous rocks. Its formation can be described by the reaction:

Contribution No. 385 from the Mineralogical Laboratory, Department of Geological Sciences, The University of Michigan, Ann Arbor, Michigan 48109, USA

1 Present address: Climax Molybdenum Co., P.O. Box 961, Battle Mountain, Nevada 89820, USA

$2 \mathrm{CMAS}=\mathrm{CaO}-\mathrm{MgO}-\mathrm{Al}_{2} \mathrm{O}_{3}-\mathrm{SiO}_{2}$.

Reprint requests to: C.A. Johnson orthopyroxene + plagioclase $=$ garnet + quartz

in oversaturated rocks and in undersaturated rocks as:

olivine + plagioclase $=$ garnet

(Ringwood and Green 1964, 1966). In principle, assemblages such as orthopyroxene-plagioclase-garnet-quartz and olivine-plagioclase-garnet will fix $P$ at a constant $T$ for given mineral compositions (Wood and Banno 1973; Wood 1975; Schmid and Wood 1976). Garnet barometry is potentially widely applicable to granulitic terranes if it can be adequately calibrated. Reaction (2) is easier to adjust for variable solid solutions because olivines are well represented as binary solutions while complete description of natural orthopyroxenes requires consideration of variable $\mathrm{MgSiO}_{3}$, $\mathrm{FeSiO}_{3}, \mathrm{CaSiO}_{3}$ and $\mathrm{MgAl}_{2} \mathrm{SiO}_{6}$ (Herzberg 1978 a).

Two different kinds of experiments have been applied to garnet reactions: those on natural rock compositions and those on simple end-member reactions. Ringwood and Green (1964, 1966), Green and Ringwood (1967) and Ito and Kennedy (1971) have investigated garnet reactions in basaltic rocks but they concentrated mainly on the plagioclase-out reaction forming eclogites. Application of these experiments below $900^{\circ} \mathrm{C}$ is difficult in any case because of uncertainties in extrapolation: reversals are difficult to interpret in these multicomponent systems and the garnet-in boundary is unlikely to be a straight line (pace Green, Ito, Kennedy and Ringwood). Until experiments on multicomponent rock systems are completely and tightly reversed over a wide range of $T$, they will be difficult to apply to metamorphic rocks.

Garnet-forming reactions have also been investigated in the simple system CMAS. Several experimenters (Kushiro and Yoder 1966; O'Hara et al. 1971; Herzberg 1972, 1976; Herzberg and Chapman 1976; Presnall 1976; Jenkins and Newton 1979; O'Neill 1981) have investigated the reactions:

forsterite + anorthite $=$ orthopyroxene

+ clinopyroxene + spinel

orthopyroxene + clinopyroxene + spinel

+ anorthite $=$ garnet

orthopyroxene + clinopyroxene + spinel $=$ garnet + forsterite.

Reaction (5) has been reversed between 800 and $1,100^{\circ} \mathrm{C}$ (Jenkins and Newton 1979; O'Neill 1981) while reactions (3) and (4) are constrained only by half-reversals above 
$900^{\circ}$ C. Obata (1976) and Herzberg (1978b) have shown that the straight line extrapolations to lower $T$ made by McGregor (1970), Whitney and McLelland (1973) and others are inappropriate. The compositions of equilibrium CMAS pyroxenes slide with $P$ and $T$ due to $\mathrm{Ca}-\mathrm{Mg}$ and $\mathrm{MgSi}$ - AlAl substitutions. Reactions (3), (4) and (5) curve markedly away from each other between 800 and $1,200^{\circ} \mathrm{C}$ as a result.

Whitney and McLelland (1973) and Whitney (1978) have applied phase equilibria in the CMAS system to olivine-bearing rocks in the Adirondacks. Using straight line extrapolations, they propose that reactions (3) and (4) cross at granulite $T$. They infer that metamorphic conditions at or near this crossing point were required to stabilize the six phase assemblage olivine-orthopyroxene-clinopyroxenegarnet-spinel-plagioclase in the Adirondacks. Sack (1980a) has calculated how several reactions, including (3) and (5), shift in $P-T$ space with changing bulk composition. He has shown that the six phase assemblage of Whitney and McLelland (1973) is stable at $730 \pm 50^{\circ} \mathrm{C}$ and $8 \pm 1 \mathrm{~kb}$ when olivine has composition $\mathrm{Fa}_{34}$ and garnet has composition $\mathrm{Gr}_{18}$ or when olivine has composition $\mathrm{Fa}_{34}$ and plagioclase has composition $\mathrm{An}_{41}$. Thus solid solutions can have substantial effects on the stability of phases in natural systems.

Garnet barometry based on results in the simplified CMAS system can be applied successfully to granulite terranes. This approach requires accurate phase equilibria in the four component system at granulite $T$ and knowledge of the effects of solid solutions to extend these results to complex natural systems.

\section{Adirondack Olivine-Bearing Metagabbros}

Quartz-undersaturated gabbros occur mainly in the eastern Adirondack Mountains as dikes, sills and small stocks from tens of meters to several kilometers in diameter (Buddington 1939). The rocks typically contain olivine, garnet, orthopyroxene, clinopyroxene and plagioclase with lesser amounts of pargasitic hornblende, biotite, green spinel and fluorapatite (Table 1). The locations of samples collected for this study are described in Appendix I. Texturally, the rocks fall into two categories. Magnesian rocks have their igneous textures preserved. Lath-like plagioclase crystals up to 5 millimeters in length are often clouded with minute inclusions of spinel (Whitney 1972; Whitney and McLelland 1973; McLelland and Whitney 1980a, b) and occasionally clinopyroxene. Coronas occur interstitial to texturally igneous pyroxenes and feldspars. Granular ortho- and clinopyroxenes rim olivine and are in turn rimmed by garnet (Fig. 1a). Coarser spinel occurs armoured by amphibole and biotite. More complete textural descriptions are in Whitney and McLelland (1973) and McLelland and Whitney $(1980 \mathrm{a}, \mathrm{b})$. Mineralogically identical but more Ferich gabbros are completely recrystallized and have finer-

Table 1. Mineral assemblages from Adirondack metagabbros

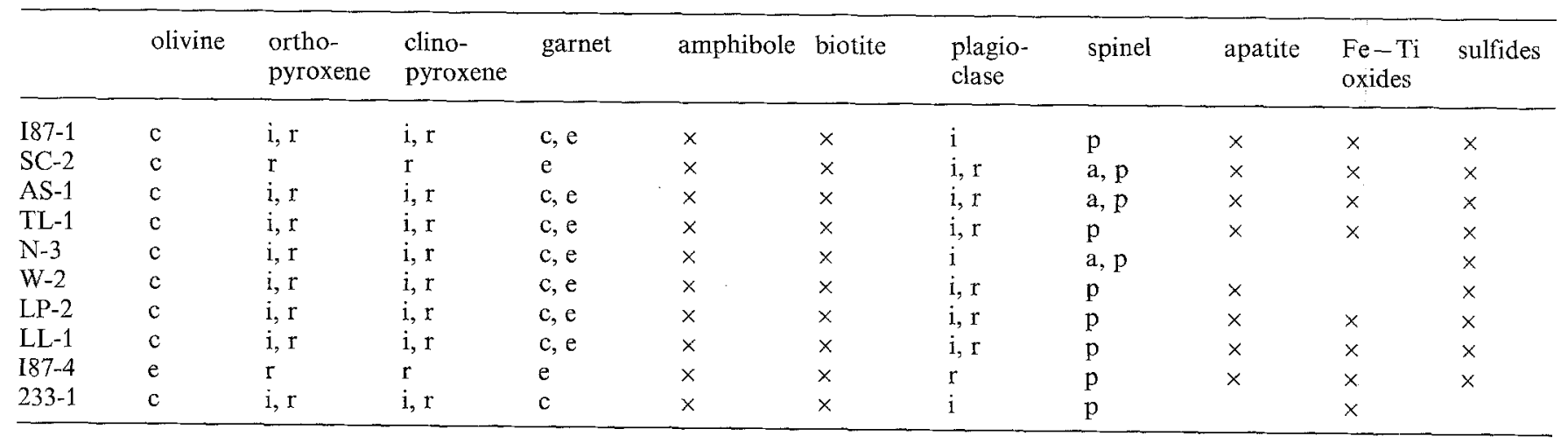

$\mathrm{i}=$ coarse igneous appearing; $\mathrm{r}=$ recrystallized metamorphic appearing; $\mathrm{c}=$ coronal; $\mathrm{e}=$ equant, not associated with coronas; $\mathrm{a}=$ armoured by hydrous phases; $\mathrm{p}=$ minute inclusions in plagioclase
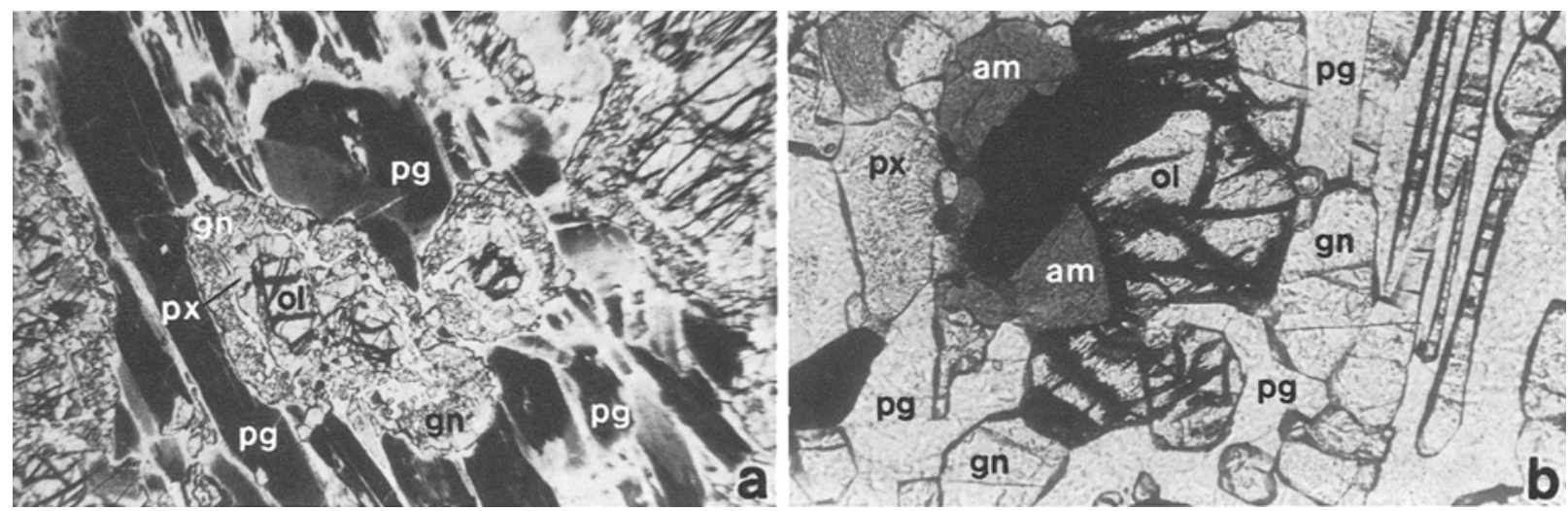

Fig. 1. a, b. (a) Well developed corona. Pyroxenes (px) surround olivine (ol) and are rimmed by garnet (gn). Euhedral plagioclase (pg) is clouded by minute spinel inclusions. Field of view is approximately $7.5 \mathrm{~mm}$ wide. (b) Recrystallized metamorphic fabric. Olivine, garnet, plagioclase, pyroxenes and amphibole (am) share grain boundaries. Field of view is approximately 0.8 mm wide. Both views in plane polarized light 
grained, equant metamorphic textures. Garnet and olivine share grain boundaries without rimming relationships (Fig. 1b). Assumptions of equilibrium in coronal and equant garnet-olivine metagabbros will be tested below.

\section{Analytical Procedures}

Mineral analyses were obtained using the University of Michigan ARL-EMX electron microprobe analyzer equipped with LiF, PET and TAP crystal spectrometers. Standard operating conditions were $15 \mathrm{kV}$ accelerating potential, $150 \mu \mathrm{A}$ emission current and 0.005 to $0.008 \mu \mathrm{A}$ sample current. Beam current was digitized. A minimum of 10,000 counts was recorded during analysis of standards which generally required counting times between 15 and $20 \mathrm{~s}$. Spectrometer data for individual minerals were collected at four or more points and were averaged to obtain an analysis. Chemical heterogeneity of mineral grains, particularly garnets, was carefully monitored and was found rarely to exceed typical microprobe uncertainty, 2 or $3 \%$ of the amount of an element present. Natural, well analyzed almandine-rich garnet (C.O. Ingamells, unpubl.), Marjalahti olivine (Univ. of Michigan), Spring Mountain kaersutite (R. Binns, written comm.), aluminous clinopyroxene (A.J. Irving, written comm.), Nain labradorite (Univ. of Michigan), Gotthard adularia (Univ. of Michigan) and Tiburon albite (B.W. Evans, written comm.) were used as standards for silicates. Synthetic forsterite, corundum, rutile, $\mathrm{ZnO}, \mathrm{V}_{2} \mathrm{O}_{5}$ and $\mathrm{Ni}_{2} \mathrm{SiO}_{4}$ in addition to naturally occurring hematite (Univ. of Michigan), chromite (M. Engi, written comm.) and almandine-rich garnet (C.O. Ingamells, unpubl.) were used as standards for spinel. All major and minor elements were identified in spinels by collecting emission spectra for $300 \mathrm{~s}$ using a Kevex Li-drifted silicon detector with Nuclear Data multichannel analyzer. This technique permitted detection of heavy elements $(Z \geqq 11)$ present in excess of approximately $0.1 \mathrm{wt} \%$. Spectrometer data were corrected for atomic number, absorption, fluorescence, background and machine drift using the computer program EMPADR VII (Rucklidge and Gasparrini 1969).

Ortho- and clinopyroxenes were normalized about 4 total cations, olivine and spinel about 3 , plagioclase about 5 and garnet about 8 to obtain mineral formulae. The amount of ferric iron was inferred from stoichiometry. Garnet was assumed to have none.

Minute spinel and clinopyroxene inclusions in plagioclase, most of which were too fine to resolve using the electron microprobe, were identified and semiquantitatively analyzed using a University of Michigan JEOL JSM-U3 scanning electron microscope equipped with a Kevex Lidrifted silicon detector and multichannel analyzer. Analyses of minute spinels in plagioclase and coarser spinels enclosed in hydrous phases from the same rock are provided for samples SC-2 and W-2 (Table 2). Data from spinels in plagioclase are used in the following calculations.

Pyroxene analyses were obtained from smaller metamorphic appearing grains. The orthopyroxenes range from $\mathrm{En}_{44} \mathrm{Fs}_{54} \mathrm{WO}_{2}$ to $\mathrm{En}_{75} \mathrm{Fs}_{24} \mathrm{Wo}_{1}$ with $\mathrm{MgTs}\left(\mathrm{MgAl} \mathrm{SiO}_{6}\right)$ components of 1 to $8 \mathrm{~mol} \%$. Clinopyroxenes vary from $\mathrm{En}_{44} \mathrm{Fs}_{9} \mathrm{Wo}_{47}$ to $\mathrm{En}_{30} \mathrm{Fs}_{23} \mathrm{Wo}_{47}$ with $\mathrm{CaTs}\left(\mathrm{CaAl}_{2} \mathrm{SiO}_{6}\right)$ contents of 4 to $12 \%$. These pyroxenes also show $\mathrm{Na}$ in excess of $\mathrm{Fe}^{3+}$ allowing calculation of a nominal Jd $\left(\mathrm{NaAlSi}_{2} \mathrm{O}_{6}\right.$ ) component of 0 to $5 \mathrm{~mol} \%$ with most values at around $4 \%$. The olivines vary from $\mathrm{Fo}_{25}$ to $\mathrm{Fo}_{72}$, the garnets from $\mathrm{Pp}_{43} \mathrm{Alm}_{39} \mathrm{Sp}_{1} \mathrm{Gr}_{17}$ to $\mathrm{Pp}_{13} \mathrm{Alm}_{63} \mathrm{Sp}_{5} \mathrm{Gr}_{20}$. Spinels range from $\mathrm{Hc}_{40} \mathrm{Sp}_{57} \mathrm{Gh}_{1} \mathrm{Mt}_{2}$ to $\mathrm{Hc}_{76} \mathrm{Sp}_{15} \mathrm{Gh}_{3} \mathrm{Mt}_{6}$ with very minor $\mathrm{V}, \mathrm{Mn}, \mathrm{Ni}, \mathrm{Ti}$ and $\mathrm{Cr}$ in solution $(\mathrm{Gh}=$ $\mathrm{ZnAl}_{2} \mathrm{O}_{4}$ ). Plagioclases change from $\mathrm{An}_{29} \mathrm{Ab}_{67} \mathrm{Or}_{4}$ to $\mathrm{An}_{49} \mathrm{Ab}_{49} \mathrm{Or}_{1}$.

\section{Phase Equilibria in the CMAS System}

Herzberg and Chapman (1976) obtained a half-reversal of reaction (3) at $1,200^{\circ} \mathrm{C}$ and $8.9 \mathrm{~kb}$. This half-reversal, the

Table 2a-f. Electron microprobe analyses of (a) olivines, (b) orthopyroxenes, (c) clinopyroxenes, (d) garnets, (e) plagioclases and (f) spinels

\begin{tabular}{|c|c|c|c|c|c|c|c|c|c|c|}
\hline & I87-1 & $\mathrm{SC}-2$ & AS-1 & TL-1 & $\mathrm{N}-3$ & W-2 & LP-2 & LL-1 & I87-4 & $233-1$ \\
\hline $\mathrm{SiO}_{2}$ & 35.42 & 36.69 & 37.27 & 36.76 & 37.09 & 38.20 & 37.66 & 36.56 & 32.81 & 34.80 \\
\hline $\mathrm{TiO}_{2}$ & 0.03 & 0.01 & 0.00 & 0.01 & 0.03 & 0.00 & 0.00 & 0.03 & 0.00 & 0.00 \\
\hline $\mathrm{Al}_{2} \mathrm{O}_{3}$ & 0.09 & 0.00 & 0.00 & 0.02 & 0.00 & 0.00 & 0.00 & 0.00 & 0.00 & 0.00 \\
\hline $\mathrm{FeO}$ & 40.85 & 30.06 & 28.82 & 30.47 & 32.89 & 25.92 & 29.99 & 38.62 & 56.56 & 45.40 \\
\hline $\mathrm{MnO}$ & 0.27 & 0.02 & 0.15 & 0.15 & 0.12 & 0.14 & 0.20 & 0.29 & 0.89 & 0.58 \\
\hline $\mathrm{MgO}$ & 24.34 & 33.72 & 34.46 & 33.35 & 30.02 & 36.92 & 33.66 & 26.43 & 10.94 & 19.74 \\
\hline $\mathrm{CaO}$ & 0.05 & 0.00 & 0.00 & 0.02 & 0.02 & 0.03 & 0.03 & 0.01 & 0.03 & 0.00 \\
\hline $\mathrm{Na}_{2} \mathrm{O}$ & 0.00 & 0.02 & 0.00 & 0.02 & 0.00 & 0.00 & 0.00 & 0.02 & 0.00 & 0.00 \\
\hline $\mathrm{K}_{2} \mathrm{O}$ & 0.00 & 0.00 & 0.00 & 0.00 & 0.00 & 0.00 & 0.00 & 0.00 & 0.00 & 0.00 \\
\hline Total & 101.05 & 100.69 & 100.71 & 100.80 & 100.17 & 101.20 & 101.54 & 101.96 & 101.22 & 100.52 \\
\hline $\mathrm{Si}$ & 1.001 & 0.980 & 0.991 & 0.983 & 1.016 & 0.996 & 0.999 & 1.010 & 1.012 & 1.017 \\
\hline $\mathrm{Al}$ & 0.002 & 0.000 & 0.000 & 0.001 & 0.000 & 0.000 & 0.000 & 0.000 & 0.000 & 0.000 \\
\hline $\mathrm{Fe}^{3+}$ & 0.000 & 0.040 & 0.018 & 0.033 & 0.000 & 0.010 & 0.002 & 0.000 & 0.000 & 0.000 \\
\hline $\mathrm{Ti}$ & 0.000 & 0.000 & 0.000 & 0.000 & 0.000 & 0.000 & 0.000 & 0.001 & 0.000 & 0.000 \\
\hline $\mathrm{Mg}$ & 1.025 & 1.340 & 1.365 & 1.330 & 1.226 & 1.434 & 1.331 & 1.089 & 0.503 & 0.859 \\
\hline $\mathrm{Fe}^{2+}$ & 0.966 & 0.632 & 0.623 & 0.649 & 0.754 & 0.555 & 0.664 & 0.893 & 1.460 & 1.109 \\
\hline $\mathrm{Mn}$ & 0.006 & 0.005 & 0.003 & 0.004 & 0.003 & 0.003 & 0.004 & 0.007 & 0.023 & 0.014 \\
\hline $\mathrm{Ca}$ & 0.002 & 0.000 & 0.000 & 0.000 & 0.001 & 0.001 & 0.001 & 0.000 & 0.001 & 0.000 \\
\hline $\mathrm{Na}$ & 0.000 & 0.000 & 0.000 & 0.000 & 0.000 & 0.000 & 0.000 & 0.000 & 0.000 & 0.000 \\
\hline $\mathrm{K}$ & 0.000 & 0.000 & 0.000 & 0.000 & 0.000 & 0.000 & 0.000 & 0.000 & 0.000 & 0.000 \\
\hline $\mathrm{Fo}_{\mathrm{O}}$ & 51.3 & 66.5 & 67.9 & 65.9 & 61,8 & 71.6 & 66.5 & 54.7 & 25.3 & 43.3 \\
\hline
\end{tabular}


Table $2 \mathrm{~b}$.

\begin{tabular}{|c|c|c|c|c|c|c|c|c|c|c|}
\hline & I $87-1$ & $\mathrm{SC}-2$ & $\mathrm{AS}-1$ & TL-1 & $\mathrm{N}-3$ & W-2 & LP-2 & LL-1 & I $87-4$ & $233-1$ \\
\hline $\mathrm{SiO}_{2}$ & 51.83 & 52.41 & 53.02 & 53.78 & 54.22 & 53.08 & 53.49 & 54.61 & 51.40 & 52.34 \\
\hline $\mathrm{TiO}_{2}$ & 0.10 & 0.09 & 0.04 & 0.06 & 0.05 & 0.02 & 0.07 & 0.06 & 0.06 & 0.07 \\
\hline $\mathrm{Al}_{2} \mathrm{O}_{3}$ & 2.02 & 3.51 & 3.28 & 2.61 & 2.70 & 3.12 & 2.74 & 1.39 & 0.47 & 1.63 \\
\hline $\mathrm{FeO}$ & 23.58 & 16.96 & 17.44 & 18.35 & 18.77 & 15.52 & 17.54 & 21.65 & 32.49 & 26.18 \\
\hline $\mathrm{MnO}$ & 0.25 & 0.14 & 0.13 & 0.20 & 0.15 & 0.12 & 0.20 & 0.27 & 0.73 & 0.51 \\
\hline $\mathrm{MgO}$ & 21.75 & 24.96 & 26.09 & 24.96 & 24.71 & 26.83 & 25.60 & 23.04 & 14.70 & 19.98 \\
\hline $\mathrm{CaO}$ & 0.63 & 0.50 & 0.34 & 0.39 & 0.45 & 0.35 & 0.36 & 0.04 & 0.76 & 0.34 \\
\hline $\mathrm{Na}_{2} \mathrm{O}$ & 0.01 & 0.00 & 0.01 & 0.01 & 0.02 & 0.01 & 0.01 & 0.02 & 0.02 & 0.00 \\
\hline $\mathrm{K}_{2} \mathrm{O}$ & 0.00 & 0.01 & 0.00 & 0.00 & 0.00 & 0.00 & 0.00 & 0.00 & 0.00 & 0.00 \\
\hline Total & 100.17 & 98.58 & 100.35 & 100.36 & 101.09 & 99.05 & 100.02 & 101.44 & 100.64 & 101.06 \\
\hline $\mathrm{Si}$ & 1.932 & 1.930 & 1.912 & 1.954 & 1.961 & 1.926 & 1.942 & 1.996 & 2.005 & 1.960 \\
\hline $\mathrm{Al}$ & 0.068 & 0.070 & 0.088 & 0.046 & 0.039 & 0.074 & 0.058 & 0.004 & 0.000 & 0.040 \\
\hline $\mathrm{Al}$ & 0.021 & 0.082 & 0.052 & 0.066 & 0.076 & 0.059 & 0.059 & 0.056 & 0.022 & 0.032 \\
\hline $\mathrm{Ti}$ & 0.003 & 0.002 & 0.001 & 0.002 & 0.001 & 0.000 & 0.002 & 0.002 & 0.002 & 0.002 \\
\hline $\mathrm{Fe}^{3+}$ & 0.042 & 0.000 & 0.034 & 0.000 & 0.000 & 0.015 & 0.000 & 0.000 & 0.000 & 0.003 \\
\hline $\mathrm{Mg}$ & 1.208 & 1.370 & 1.403 & 1.352 & 1.332 & 1.451 & 1.385 & 1.255 & 0.855 & 1.115 \\
\hline $\mathrm{Fe}^{2+}$ & 0.693 & 0.522 & 0.492 & 0.558 & 0.568 & 0.456 & 0.532 & 0.662 & 1.060 & 0.817 \\
\hline $\mathrm{Mn}$ & 0.008 & 0.004 & 0.004 & 0.006 & 0.005 & 0.004 & 0.006 & 0.008 & 0.024 & 0.016 \\
\hline $\mathrm{Ca}$ & 0.025 & 0.020 & 0.013 & 0.015 & 0.017 & 0.014 & 0.014 & 0.016 & 0.032 & 0.014 \\
\hline $\mathrm{Na}$ & 0.001 & 0.000 & 0.001 & 0.001 & 0.001 & 0.001 & 0.001 & 0.001 & 0.001 & 0.000 \\
\hline $\mathrm{K}$ & 0.000 & 0.000 & 0.000 & 0.000 & 0.000 & 0.000 & 0.000 & 0.000 & 0.000 & 0.000 \\
\hline Wo & 1.3 & 1.0 & 0.7 & 0.8 & 0.9 & 0.7 & 0.7 & 0.8 & 1.6 & 0.7 \\
\hline En & 62.7 & 71.6 & 73.5 & 70.2 & 69.5 & 75.5 & 71.7 & 66.3 & 43.9 & 57.3 \\
\hline Fs & 36.0 & 27.3 & 25.8 & 29.0 & 29.6 & 23.7 & 27.5 & 32.9 & 54.4 & 42.0 \\
\hline
\end{tabular}

Table 2c.

\begin{tabular}{|c|c|c|c|c|c|c|c|c|c|c|}
\hline & I87-1 & $\mathrm{SC}-2$ & $\mathrm{AS}-1$ & TL-1 & N-3 & W-2 & LP-2 & LL-1 & I87-4 & $233-1$ \\
\hline $\mathrm{SiO}_{2}$ & 51.58 & 50.33 & 51.90 & 51.63 & 53.39 & 51.48 & 51.28 & 52.90 & 52.32 & 52.87 \\
\hline $\mathrm{TiO}_{2}$ & 0.37 & 0.72 & 0.35 & 0.26 & 0.11 & 0.26 & 0.66 & 0.25 & 0.17 & 0.16 \\
\hline $\mathrm{Al}_{2} \mathrm{O}_{3}$ & 3.79 & 5.32 & 3.54 & 4.90 & 3.86 & 4.22 & 4.35 & 3.77 & 2.26 & 1.96 \\
\hline $\mathrm{FeO}$ & 8.88 & 6.86 & 6.98 & 6.29 & 7.08 & 4.81 & 5.96 & 7.18 & 14,42 & 8.81 \\
\hline $\mathrm{MnO}$ & 0.18 & 0.01 & 0.06 & 0.09 & 0.10 & 0.06 & 0.09 & 0.18 & 0.36 & 0.21 \\
\hline $\mathrm{MgO}$ & 12.58 & 13.32 & 14.23 & 13.75 & 13.54 & 13.35 & 13.20 & 13.58 & 9.68 & 13.04 \\
\hline $\mathrm{CaO}$ & 20.72 & 22.02 & 21.08 & 21.77 & 22.11 & 23.21 & 22.50 & 22.43 & 20.90 & 23.15 \\
\hline $\mathrm{Na}_{2} \mathrm{O}$ & 1.17 & 0.98 & 1.09 & 1.12 & 1.13 & 0.88 & 0.96 & 0.78 & 1.24 & 0.65 \\
\hline $\mathrm{K}_{2} \mathrm{O}$ & 0.01 & 0.00 & 0.00 & 0.00 & 0.00 & 0.00 & 0.00 & 0.00 & 0.00 & 0.00 \\
\hline Total & 99.27 & 99.56 & 99.23 & 99.83 & 101.32 & 98.27 & 98.99 & 101.07 & 101.36 & 100.87 \\
\hline $\mathrm{Si}$ & 1.926 & 1.860 & 1.920 & 1.895 & 1.940 & 1.921 & 1.906 & 1.933 & 1.961 & 1.952 \\
\hline $\mathrm{Al}$ & 0.074 & 0.140 & 0.080 & 0.105 & 0.060 & 0.079 & 0.094 & 0.067 & 0.039 & 0.048 \\
\hline $\mathrm{Al}$ & 0.093 & 0.092 & 0.074 & 0.107 & 0.105 & 0.106 & 0.097 & 0.095 & 0.061 & 0.037 \\
\hline $\mathrm{Ti}$ & 0.010 & 0.020 & 0.010 & 0.007 & 0.003 & 0.007 & 0.016 & 0.007 & 0.005 & 0.004 \\
\hline $\mathrm{Fe}^{3+}$ & 0.047 & 0.078 & 0.064 & 0.068 & 0.031 & 0.023 & 0.030 & 0.015 & 0.058 & 0.049 \\
\hline $\mathrm{Mg}$ & 0.700 & 0.734 & 0.785 & 0.752 & 0.733 & 0.743 & 0.731 & 0.739 & 0.541 & 0.718 \\
\hline $\mathrm{Fe}^{2+}$ & 0.231 & 0.134 & 0.152 & 0.125 & 0.184 & 0.127 & 0.155 & 0.204 & 0.394 & 0.223 \\
\hline $\mathrm{Mn}$ & 0.006 & 0.000 & 0.002 & 0.003 & 0.003 & 0.002 & 0.003 & 0.006 & 0.012 & 0.007 \\
\hline $\mathrm{Ca}$ & 0.829 & 0.872 & 0.835 & 0.856 & 0.861 & 0.928 & 0.896 & 0.878 & 0.840 & 0.916 \\
\hline $\mathrm{Na}$ & 0.085 & 0.070 & 0.078 & 0.080 & 0.078 & 0.064 & 0.069 & 0.055 & 0.090 & 0.047 \\
\hline K & 0.000 & 0.000 & 0.000 & 0.000 & 0.000 & 0.000 & 0.000 & 0.000 & 0.000 & 0.000 \\
\hline Wo & 47.1 & 50.1 & 47.2 & 49.4 & 48.4 & 51.6 & 50.2 & 48.2 & 47.2 & 49.3 \\
\hline En & 39.8 & 42.2 & 44.2 & 43.4 & 41.2 & 41.3 & 41.0 & 40.6 & 30.3 & 38.7 \\
\hline Fs & 13.1 & 7.7 & 8.6 & 7.2 & 10.3 & 7.1 & 8.7 & 11.2 & 22.5 & 12.0 \\
\hline
\end{tabular}

most restrictive reported in the literature, provides an upper $P$ limit for the stability of forsterite +anorthite. Due to $\mathrm{Ca}-\mathrm{Mg}$ and $\mathrm{MgSi}-\mathrm{AlAl}$ exchange however, the run product pyroxenes were not end-member diopside or enstatite. $\mathrm{CaTs}$ and enstatite in the equilibrium clinopyroxene were determined using X-ray diffraction (XRD) data (Herzberg and Chapman 1976). For the equilibrium orthopyroxene, estimation of the diopside component (Lindsley and Dixon 1976) and the assumption that the mole fraction of $\mathrm{Al}$ in the M1 site of the orthopyroxene $\left(X_{\mathrm{M} 1, \mathrm{opx}}^{\mathrm{A} 1}\right)$ is the same as 
Table $2 \mathrm{~d}$.

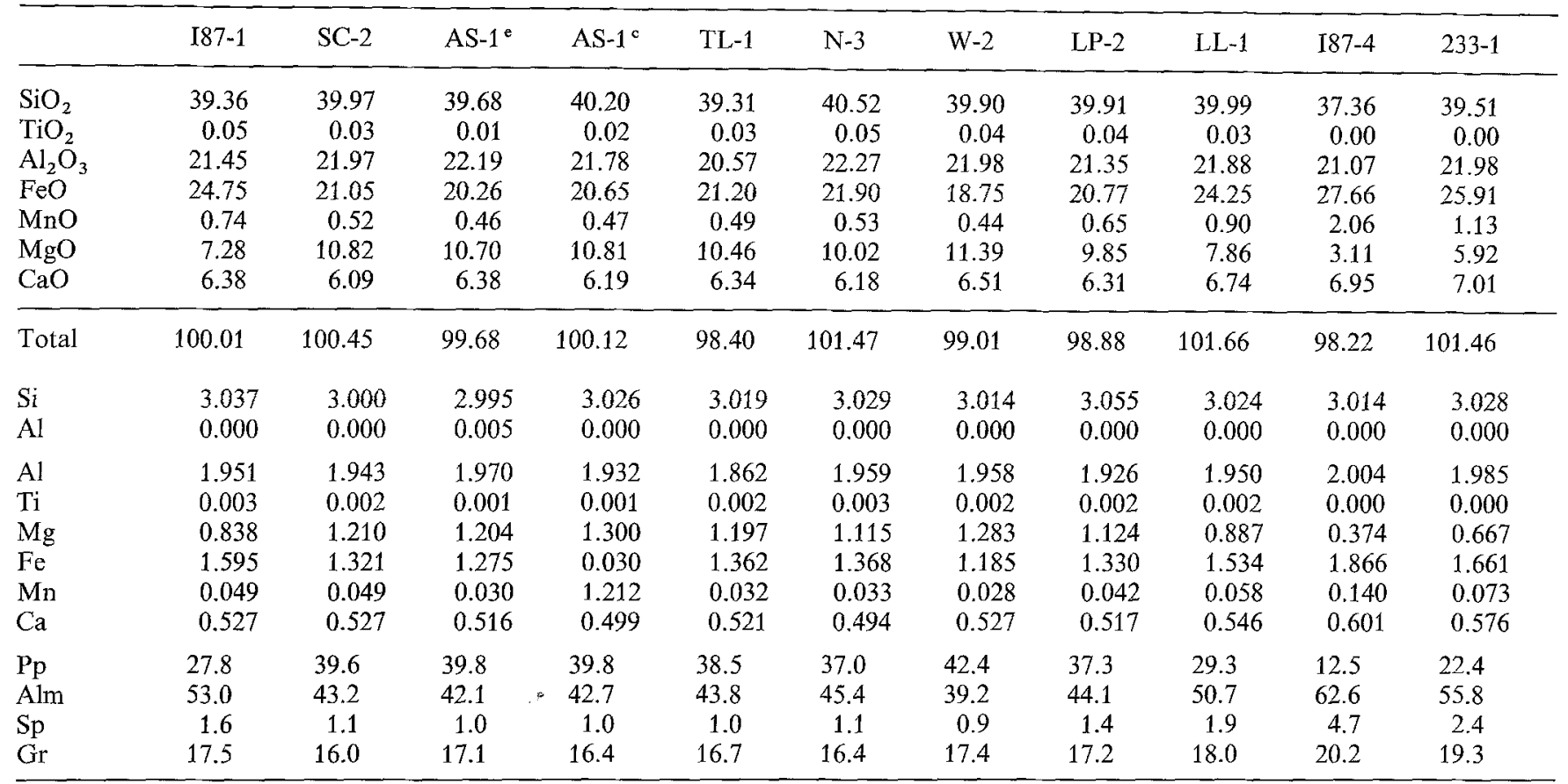

c Coronal

e Equant, not associated with coronas

Table 2e.

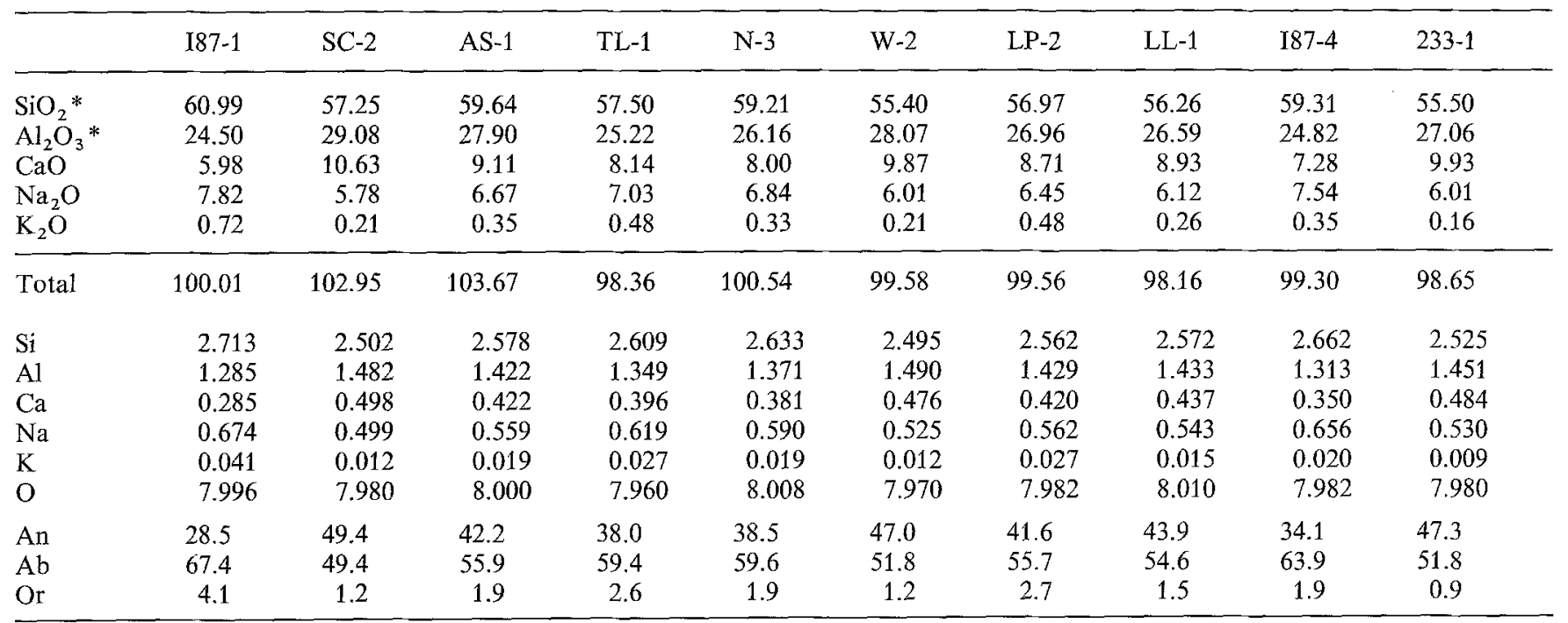

* Si and $\mathrm{Al}$ were determined by fixed stoichiometry. By this scheme approximately 85 weight percent of a plagioclase is calculated from an analysis of 15 weight percent of the total. As a result, oxide totals of 95 to 105 are roughly equivalent to totals of 99 to 101 if $\mathrm{Al}$ and Si had been measured

that in the clinopyroxene ( $\left.X_{\mathrm{M} 1, \mathrm{cpx}}^{\mathrm{Al}}\right)$ permit estimation of the composition $^{3}$.

3 This assumption, used by Herzberg and Chapman, may in fact overestimate $X_{\mathrm{MI}, 0 \mathrm{px}}^{\mathrm{Al}}$. Data from naturally occurring pyroxene pairs in granulites and lherzolites (Wood 1975; Bohlen and Essene 1978a; Carswell et al. 1979; Brown et al. 1980; this report) seem to indicate that $X_{\mathrm{M} 1, \mathrm{Apx}}^{\mathrm{Al}}$ is on the order of $50 \%$ larger than $X_{\mathrm{M} 1, \mathrm{cpx}}^{\mathrm{A1}}$. We assume, nevertheless, that $X_{\mathrm{M} 1 \text {, opx }}^{\mathrm{Al}}=$ $X_{\mathrm{M} 1 \text {, cp }}^{\mathrm{Al}}$ since the errors introduced in the resulting enstatite activities are small.
Knowing the reduced activites (Wood and Banno 1973) of enstatite and diopside in the experimental assemblage, one can calculate a maximum Gibbs free energy for the end-member equilibrium:

$$
\begin{aligned}
& 2 \mathrm{Mg}_{2} \mathrm{SiO}_{4}+\mathrm{CaAl}_{2} \mathrm{Si}_{2} \mathrm{O}_{8} \\
& \quad=2 \mathrm{MgSiO}_{3}+\mathrm{CaMgSi}_{2} \mathrm{O}_{6}+\mathrm{MgAl}_{2} \mathrm{O}_{4} \\
& \text { forsterite + anorthite }
\end{aligned}
$$

$$
=\text { enstatite }+ \text { diopside }+ \text { spinel }
$$

using the relation: 
Table 2f.

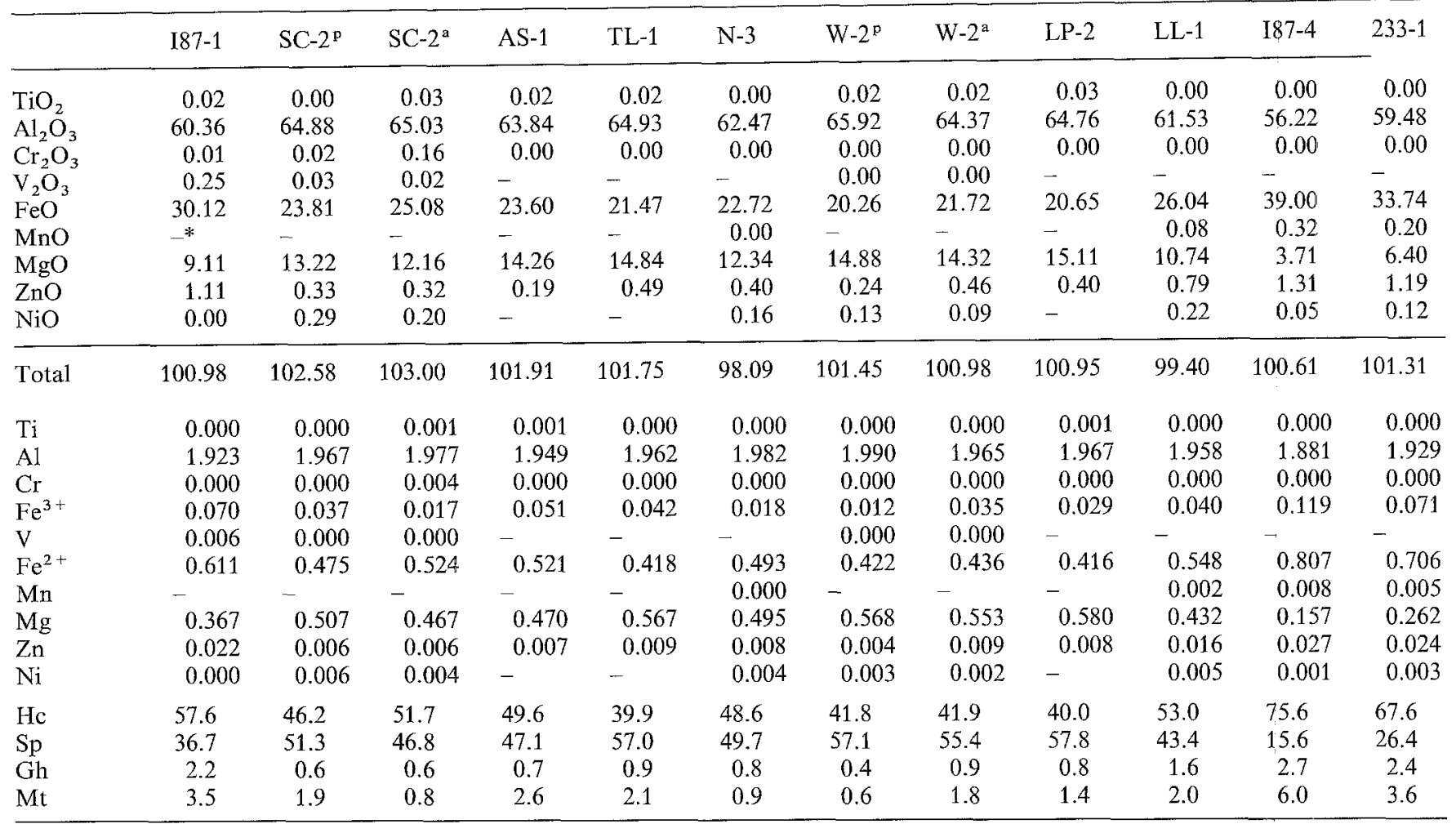

* no analytical data were obtained

a armoured by hydrous phases

$\mathrm{p}$ minute inclusions in plagioclase

$\Delta G_{\mathrm{T}}^{\mathrm{P}}=-\mathrm{RT} \ln \left(\mathrm{K}_{\gamma}^{0}(6) / K \gamma(3)\right)$

where $K^{0} \gamma(6)$ is the equilibrium constant for end-member equilibrium (6) $\left(K^{0} \gamma(6)=1\right)$ and $K \gamma(3)$ is the equilibrium constant for the run product assemblage. $\Delta G_{1200^{\circ} \mathrm{C}}^{8.9 \mathrm{~kb}}(6)$ is at most $9.66 \mathrm{~kJ} / \mathrm{mol}$ indicating that equilibrium (6) is metastable with respect to reaction (3). The location of equilibrium (6) in $P-T$ space has been calculated by solving:

$d(\Delta G)=\Delta V d P-\Delta S d T=0$

where for each phase of interest:

$d V=-\int \beta V d P+\int \alpha V d T$ and $d S=-\int \alpha d P$.

We have done this using the computer program EQUILI (Wall and Essene unpubl.) and the results are shown in Fig. $2^{4}$. Note that since Fig. 2 is based on a half-reversal, it represents the high $P$ limit for equilibrium (6).

Reaction (5) has been reversed at $900^{\circ} \mathrm{C}$ and $15.0 \pm 0.5 \mathrm{~kb}$ and $1,000^{\circ} \mathrm{C}$ and $16.0 \pm 0.5 \mathrm{~kb}$ (Jenkins and Newton 1979). As in the previous experiments, the run product pyroxenes undoubtedly showed some degree of mutual solubility and small amounts of Tschermak's com-

$4 S_{298}^{0}$ and $S_{\mathrm{T}}^{0}$ for the phases were taken from Robie et al. (1978) with the exception of orthoenstatite, diopside and forsterite which were taken from Krupka et al. (1979), Krupka et al. (1980) and Robie (unpubl.), respectively. Values for $V_{298}^{0}$ were taken from Robie et al. (1978). Thermal expansion and compressibility data were obtained from Skinner (1966) and Birch (1966). Where data were unavailable, $\alpha$ and $\beta$ were approximated using values for structurally similar phases. In all cases, it was assumed that $\alpha_{\mathrm{T}}^{\mathrm{P}}=\alpha_{\mathrm{T}}^{0}$ and $\beta_{\mathrm{T}}^{\mathrm{P}}=\beta_{298}^{\mathrm{P}}$.

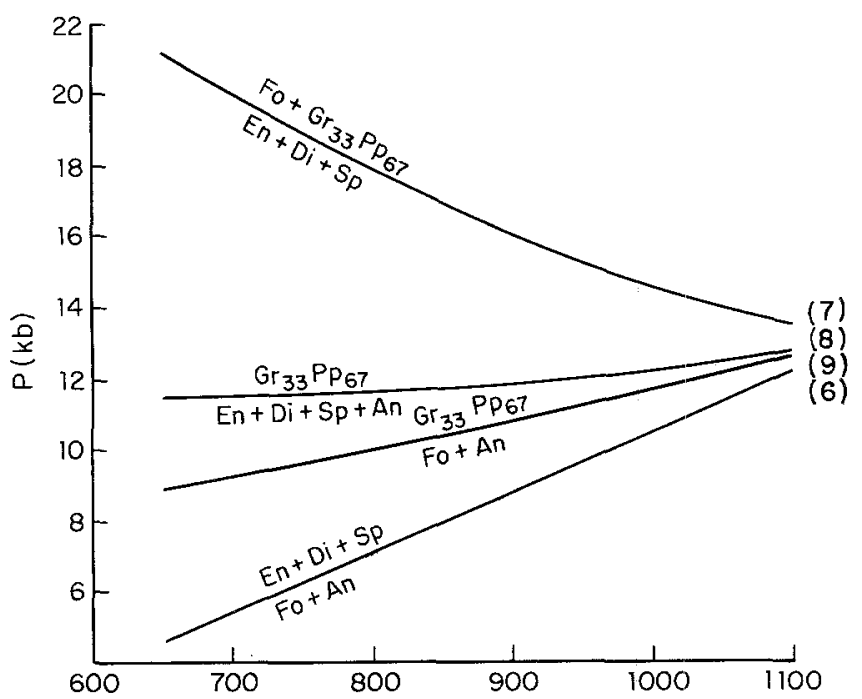

Fig. 2. Reactions (6), (7), (8) and (9) in the CMAS system. Equilibria located using experimental data and the Fortran program EQUILI (see text for explanation)

ponent. As in the above calculation, equilibrium compositions have been estimated using the diopside-enstatite solvus (Lindsley and Dixon 1976), data on the solubility of CaTs in diopside (Herzberg 1978a) and the assumption that $X_{\mathrm{M} 1 \text {, cpx }}^{\mathrm{Ai}}=X_{\mathrm{M} 1, \mathrm{opx}}^{\mathrm{Al}}$. Garnet composition determined using XRD data was $\mathrm{Gr}_{15} \mathrm{Pp}_{85}$ (Jenkins and Newton 1979). For each reversal one can calculate a Gibbs free energy for the end-member analog of reaction (5): 
$2 \mathrm{MgSiO}_{3}+\mathrm{CaMgSi}_{2} \mathrm{O}_{6}+\mathrm{MgAl}_{2} \mathrm{O}_{4}$

$=\mathrm{CaMg}_{2} \mathrm{Al}_{2} \mathrm{Si}_{3} \mathrm{O}_{12}+\mathrm{Mg}_{2} \mathrm{SiO}_{4}$

enstatite + diopside + spinel

$=$ grossular $_{33}$ pyrope $_{67}+$ forsterite

$\Delta G_{900^{\circ} \mathrm{C}}^{15.0 \mathrm{~kb}}(7)$ and $\Delta G_{1,000^{\circ} \mathrm{C}}^{16.0 \mathrm{~kb}}(7)$ are 0.08 and $-0.29 \mathrm{~kJ} / \mathrm{mol}$, respectively. Pyroxene activities were calculated as above; garnet activities were taken to be $\left(a_{\mathrm{gr}}\right)\left(a_{\mathrm{pp}}\right)^{2}$. A regular solution model $\left(W_{\mathrm{gr}-\mathrm{pp}}=4180-1.2 \mathrm{~T}\left({ }^{\circ} \mathrm{C}\right)\right)$ was used to calculate grossular and pyrope activities (Perkins 1979). Equilibrium (7) has been located and extrapolated in $P-T$ space using EQUILI $^{5}$ such that it agrees as well as possible with calculated $\Delta G$ at both 900 and $1,000^{\circ} \mathrm{C}$. The slope of the equilibrium shown by EQUILI does not agree particularly well with the slope derived from experiments on reaction (5) in the 900 to $1,000^{\circ} \mathrm{C}$ range. The disagreement suggests an uncertainty of $\pm 1 \mathrm{~kb}$ in the location of equilibrium (7) at granulite $T$. It is important to note that on the univariant line the equilibrium constant for equilibrium (7), with the activity of $\mathrm{Gr}_{33} \mathrm{Pp}_{67}$ defined as above, is not unity. The equilibrium constant in fact changes along the univariant curve since grossular and pyrope activities are functions of $T$.

The Gibbs free energy for the reaction:

$$
\begin{aligned}
& 2 \mathrm{MgSiO}_{3}+\mathrm{CaMgSi}_{2} \mathrm{O}_{6}+\mathrm{MgAl}_{2} \mathrm{O}_{4} \\
& \quad+\mathrm{CaAl}_{2} \mathrm{Si}_{2} \mathrm{O}_{8}=2 \mathrm{CaMg}_{2} \mathrm{Al}_{2} \mathrm{Si}_{3} \mathrm{O}_{12} \\
& \text { enstatite + diopside }+ \text { spinel } \\
& \quad+\text { anorthite }=\text { grossular } \\
& \text { gyrope }
\end{aligned}
$$

can now be calculated by summing the Gibbs free energies for equilibria (6) and (7):

$\Delta G_{\mathrm{T}}^{\mathrm{P}}(8)=\Delta G_{\mathrm{T}}^{\mathrm{P}}(6)+2 \Delta G_{\mathrm{T}}^{\mathrm{P}}(7)$.

At constant $T$, this reduces to:

$\Delta G_{\mathrm{T}}^{\mathrm{P}}(8)=\int \Delta V(6) d P+2 \int \Delta V(7) d P$.

Maximum equilibrium $P$ for reaction (8) are 11.5, 11.9 and $12.8 \mathrm{~kb}$ at 700,900 and $1,100^{\circ} \mathrm{C}$, respectively (Fig. 2). Again, since the garnet required to balance this reaction is not end-member in composition, the equilibrium constant (where $a_{\mathrm{gn}}$ is defined as $\left.\left(a_{\mathrm{gr}}\right)\left(a_{\mathrm{pp}}\right)^{2}\right)$ changes as a function of $T$ and is nowhere equal to one.

The Gibbs free energy for the reaction:

$\mathrm{Mg}_{2} \mathrm{SiO}_{4}+\mathrm{CaAl}_{2} \mathrm{Si}_{2} \mathrm{O}_{8}=\mathrm{CaMg}_{2} \mathrm{Al}_{2} \mathrm{Si}_{3} \mathrm{O}_{12}$

forsterite + anorthite $=$ grossular $_{33}$ pyrope $_{67}$

can also be calculated by summing the free energies of equilibria (6) and (7):

$\Delta G_{\mathrm{T}}^{\mathrm{P}}(9)=\Delta G_{\mathrm{T}}^{\mathrm{P}}(6)+\Delta G_{\mathrm{T}}^{\mathrm{P}}(7)$.

Solution of the equivalent equation:

$\Delta G_{\mathrm{T}}^{\mathrm{P}}(9)=\int \Delta V(6) d P+\int \Delta V(7) d P$

at 700,900 and $1,100^{\circ} \mathrm{C}$ gives maximum equilibrium $P$ of $9.2,10.8$ and $12.6 \mathrm{~kb}$, respectively (Fig. 2). Reaction (9) is in fact metastable with respect to reactions (6) and (8).

Values for $\Delta G(\mathrm{rxn})$ derived here are compared with values calculated using Robie et al. (1978) in Table 3. The

$5 S_{298}^{0}$ and $S_{\mathrm{T}}^{0}$ for $\mathrm{Gr}_{33} \mathrm{Pp}_{67}$ were obtained by adding an ideal mixing term $(15.86 \mathrm{~J} / \mathrm{mol})$ and an excess mixing term (Haselton and Westrum 1980) to a linear combination of the end-members grossular and pyrope (Robie et al. 1978). $V_{298}^{0}$ for the same phase was calculated from the partial molar volumes of Cressey et al (1978)
Table 3. Derived and calculated (Robie et al. 1978) Gibbs free energy data

\begin{tabular}{lll}
\hline & This paper & Robie et al. $(1978)^{*}$ \\
\hline$\Delta G_{1,200^{\circ} \mathrm{C}}^{8.9 \mathrm{~kb}}(6)$ & $\leqq 9.66 \mathrm{~kJ} / \mathrm{mole}$ & $438.4 \mathrm{~kJ} / \mathrm{mole}$ \\
$\Delta G_{900^{\circ} \mathrm{C}}^{15.0)}$ & 0.08 & -459.8 \\
$\Delta G_{1,000^{\circ} \mathrm{C}}^{16.0 \mathrm{~kb}}(7)$ & -0.29 & -453.5 \\
$\Delta G_{900^{\circ} \mathrm{C}}^{11.6)}$ & $\leqq 0.0$ & -474.5 \\
$\Delta G_{900^{\circ} \mathrm{C}}^{10.8)}$ & $\leqq 0.0$ & 6.6 \\
\hline
\end{tabular}

* Ideal and excess (Haselton and Westrum 1980) mixing terms were included in the free energy value for $\mathrm{Gr}_{33} \mathrm{Pp}_{67}$.

large discrepancies suggest that there are large errors in the tabulated Gibbs free energies of formation for clinoenstatite, diopside and/or spinel.

\section{Order-Disorder in Spinel}

A problem in extrapolating equilibria (6) and (7) to lower $T$ and applying equilibria (6), (7) and (8) to rocks involves the potential for small amounts of inverse character in spinel. Synthetic spinels annealed above $800^{\circ} \mathrm{C}$ may show a degree of inversion of 0.10 to 0.15 while natural spinels are completely normal (Hafner and Laves 1961; Stoll et al. 1964). A discrepancy may therefore exist between the locations of equilibria (6) and (7) for synthetic phases involving a spinel with some disorder and the locations of the same reactions for more ordered natural phases.

Following the development of Navrotsky and Kleppa (1967), 10\% inverse character in spinel $\left(\left(\mathrm{Mg}_{0.9} \mathrm{Al}_{0.1}\right)\right.$ $\left.\left(\mathrm{Al}_{1.9} \mathrm{Mg}_{0.1}\right) \mathrm{O}_{4}\right)$ results in a disordering enthalpy given by:

$\Delta H=-\mathrm{RT} \ln \frac{x^{2}}{(1-x)(2-x)}$

where $x$ is the fraction of tetrahedral Al. At $1,200^{\circ} \mathrm{C}$, this adds $6.3 \mathrm{~kJ} / \mathrm{mol}$ to the spinel phase. Thus for real rocks (assuming zero disordering entropy), equilibrium (6) might lie at $17.2 \mathrm{~kb}$, some $3.2 \mathrm{~kb}$ above the calculated location (Fig. 2) at $1,200^{\circ} \mathrm{C}$. Similarly, at $900^{\circ} \mathrm{C}$, equilibrium (7) might, for ordered spinel, lie at $8.2 \mathrm{~kb}$, some $6.9 \mathrm{~kb}$ below the calculated location (Fig. 2).

Disorder would have no effect on the location of reaction (9) since the experimental errors introduced by using synthetic spinel would exactly cancel in summing $\Delta G(6)$ and $\Delta G(7)$ at the same $T$. The calculated location of reaction (8), since it contains spinel, may be at erroneously high $P$. This possible error would be on the order of $0.2 \mathrm{~kb}$ at granulite $T$ and may contribute to the fact that reaction (8) gives Adirondack $P$ which seem 1 to $2 \mathrm{~kb}$ high.

\section{Phase Equilibria in Natural Systems}

The equilibria in Fig. 2 have been developed for the simple CMAS system. The remaining task is to extend these results to natural systems involving many more than four components.

Each of the ten samples used in this study contains univariant assemblages corresponding to reactions (8) and (9). 
Equilibration $T$ for each assemblage was assumed to be the same as that of nearby more felsic rocks as determined by feldspar and $\mathrm{Fe}-\mathrm{Ti}$ oxide thermometry (Bohlen et al. 1980b). Small corrections were made for the regional $T$ gradient in the Adirondacks which has been documented by feldspar and $\mathrm{Fe}-\mathrm{Ti}$ oxide thermometry and supported by other thermometers (Brown et al. 1978; Valley and O'Neil 1981) and $T$ sensitive phase equilibria (Bohlen and Essene 1978 b; Valley and Essene 1980a, b). At a given $T$, the following relation will permit calculation of equilibrium $P$ for an assemblage of known reduced activites:

$\int \Delta V d P=-\mathrm{R} T \ln \left(K \gamma / K^{0} \gamma\right)$

where $K \gamma$ is the equilibrium constant for the naturally occurring assemblage and $K^{0} \gamma$ is the equilibrium constant for an end-member reaction. This calculation is critically dependent on activity-composition relations for phases involved in the reactions.

Garnet activities were calculated using Ganguly and Kennedy's (1974) formulation for multicomponent garnets. Mixing parameters were assumed to be $T$ dependent:

$W_{\text {gr-pp }}(\mathrm{kcal})=4,180-1.2 T\left({ }^{\circ} \mathrm{C}\right)$,

$W_{\mathrm{pp}-\mathrm{al}}^{\mathrm{gr}-\mathrm{pp}}=3,480-1.2 \mathrm{~T}, \quad W_{\mathrm{al}-\mathrm{gr}}=1,050-1.25 \mathrm{~T}$

with uncertainties of approximately $\pm 0.5 \mathrm{kcal}$ (Perkins 1979). The spessartine component in garnets from Adirondack metagabbros is typically less than $5 \mathrm{~mol} \%$. It was assumed to be zero in calculating $\mathrm{Gr}_{33} \mathrm{Pp}_{67}$ activities introducing only very small errors in the results. Forsterite activities were obtained from the data of Engi (1980). Estatite and diopside activities were calculated using interpolations of Saxena's (1973) and Froese and Gordon's (1974) activity coefficients after determining cation distributions in each case as proposed by Wood and Banno (1973). The data of Saxena (1973) differ from those of Sack (1980 b) in that they predict a positive rather than a negative deviation from ideality for orthoferrosilite-enstatite solutions at granulite $T$. For the orthopyroxene compositions considered here, the discrepancy in calculated enstatite activities is approximately $10 \%$. For reaction (8), $P$ calculated using Saxena's activities agrees better with other Adirondack barometers than $P$ calculated using Sack's activities. Anorthite activities were obtained from the data of Seil and Blencoe (1979), provided by Blencoe (written comm. 1980). These data are similar to those of Orville (1972), but provide for a small $T$ dependence. Finally, spinel $\left(\mathrm{MgAl}_{2} \mathrm{O}_{4}\right)$ activities were calculated using an ideal two-site model $\left(a_{\mathrm{sp}}=\left(X_{\mathrm{Mg}}\right)\left(X_{\mathrm{A} 1}\right)^{2}\right)$. The similar ionic radii of $\mathrm{Fe}^{2+}$ and $\mathrm{Mg}^{2+}$ (Shannon 1976) and the fact that $\mathrm{MgAl}_{2} \mathrm{O}_{4}$ and $\mathrm{FeAl}_{2} \mathrm{O}_{4}$ show continuous solid solution suggest that hercynite-spinel solutions do not show a major deviation from ideality and an ideal ionic model may be a reasonable choice.

Table 4 shows calculated $P$ for each of ten Adirondack rocks. The shifts in reactions (8) and (9), the lowest $P$ garnet-forming reactions, were determined for Adirondack compositions. The regional distributions of the results are shown in Figs. 3 and 4.

Areas of uncertainty associated with these calculations are several. Jenkins and Newton (1979) constrained reaction (5) to $\pm 0.5 \mathrm{~kb}$ while Kushiro and Yoder (1966) provided only a half-reversal of reaction (3). Thus original experimental uncertainty is at least $\pm 0.5 \mathrm{~kb}$. Errors involved in estimating run product compositions and calculating $\Delta G$ for end-member reactions are probably small. Several run
Table 4. Inferred equilibration $T$ (Bohlen et al. 1980b), equilibrium constants and calculated $P$ for 10 Adirondack metagabbros. $K \gamma(8)$ and $K \gamma(9)$ are equilibrium constants for the reactions: $2 \mathrm{En}+\mathrm{Di}+$ $\mathrm{Sp}+\mathrm{An}=2 \mathrm{Gr}_{33} \mathrm{Pp}_{67}$ and $\mathrm{FO}_{\mathrm{O}}+\mathrm{An}=\mathrm{Gr}_{33} \mathrm{Pp}_{67}$, respectively

\begin{tabular}{llllll}
\hline Sample No. & $T\left({ }^{\circ} \mathrm{C}\right)$ & $K \gamma(8)$ & $P(8)$ & $K \gamma(9)$ & $P(9)$ \\
\hline I87-1 & 725 & 0.105 & 9.9 & 0.273 & 7.8 \\
SC-2 & 650 & 0.109 & 9.5 & 0.236 & 6.5 \\
AS-1 & 750 & 0.103 & 9.9 & 0.243 & 7.7 \\
TL-1 & 725 & 0.108 & 9.9 & 0.279 & 7.9 \\
N-3 & 750 & 0.086 & 9.5 & 0.242 & 7.7 \\
W-2 & 700 & 0.114 & 9.9 & 0.269 & 7.5 \\
LP-2 & 750 & 0.069 & 8.9 & 0.215 & 7.3 \\
LL-1 & 700 & 0.073 & 8.8 & 0.204 & 6.6 \\
I87-4 & 725 & 0.064 & 8.6 & 0.142 & 5.7 \\
233-1 & 700 & 0.056 & 8.1 & 0.148 & 5.6 \\
\hline
\end{tabular}

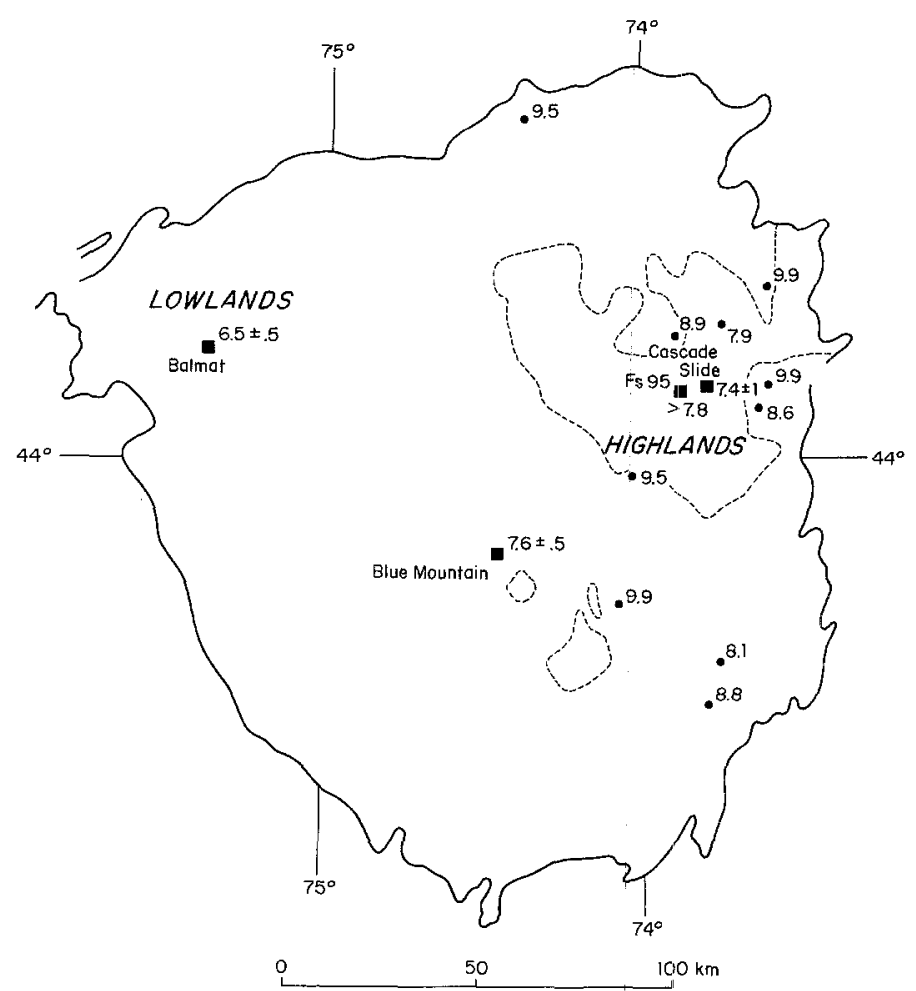

Fig. 3. Outline of Precambrian rocks in the Adirondacks. Areas enclosed by dashed lines represent anorthosite. $\bullet$ indicates metamorphic $P$ calculated using reaction (8). indicates metamorphic $P$ constraint explained in text $\mathrm{Fs}_{95}$ in Mount Marcy quad, akermanite-monticellite-wollastonite at Cascade Slide, kyanite at Blue Mountain, sphalerite-pyrite-pyrrhotite at Balmat)

product components were measured by the experimenters and the run products were close enough to end-member compositions that the activity models probably give fairly accurate results. Slight disorder in experimental spinel would cause errors of several $\mathrm{kb}$ in the locations of equilibria (6) and (7). These errors cancel in calculating the location of reaction (9) and may in part account for the apparent errors of 1 to $2 \mathrm{~kb}$ in $P$ calculated from reaction (8) as explained below. Slight disagreement of the EQUILI extrapolation of reaction (7) from $1,000^{\circ} \mathrm{C}$ with $\Delta G$ for the same reaction derived from the reversal at $900^{\circ} \mathrm{C}$ suggests that there may be an error of perhaps $\pm 1 \mathrm{~kb}$ in the location 
of reaction (7) at granulite $T$. A final source of uncertainty in calculated $P$ is associated with calculating activities of components in complex natural phases. Considering these uncertainties and comparing results in the Adirondacks with independent $P$ constraints, results from reaction (9) probably have an uncertainty of $\pm 1 \mathrm{~kb}$; results from reaction (8) appear to be systematically in error by as much as $2 \mathrm{~kb}$. These uncertainties apply to assemblages with olivine more $\mathrm{Mg}$-rich than $\mathrm{Fo}_{50}$.

\section{Discussion}

Metamorphic $P$ in the Adirondacks can be constrained by several independent equilibria. Sphalerite barometry and calcite-dolomite thermometry in the Balmat-Edwards district (NW Adirondacks) indicate a metamorphic $P$ of $6.5 \pm 0.5 \mathrm{~kb}$ at $625 \pm 25^{\circ} \mathrm{C}$ (Brown et al. 1978). The coexistence of akermanite, monticellite and wollastonite at Cascade Slide requires $7.4 \pm 1.0 \mathrm{~kb}$ and $750 \pm 30^{\circ} \mathrm{C}$ (Valley and Essene 1980a). The occurrence of ferrosilite $95\left(\mathrm{Fe}^{2+} /\right.$ $\left(\mathrm{Fe}^{2+}+\mathrm{Mg}\right)$ ) in the Mount Marcy (Jaffe et al. 1978) and Saranac Lake (Bohlen et al. 1980a) quads gives a $P$ minimum of $7.8 \mathrm{~kb}$ for a $T$ of $750^{\circ} \mathrm{C}$ (Bohlen et al. $1980 \mathrm{~b}$; Bohlen and Boettcher 1981). Further, sillimanite occurs throughout the Adirondacks and restricts $P$ to less than $6.0 \pm 0.5 \mathrm{~kb}$ in the Lowlands and southern Adirondacks and less than $9.0 \pm 0.5 \mathrm{~kb}$ in the Highlands (Newton 1966; Richardson et al. 1968; Holdaway 1971). A single kyanite occurrence at Blue Mountain (Boone 1978), itself in close proximity to several sillimanite localities, requires $7.6 \pm 0.5 \mathrm{~kb}$ for a $T$ of $730 \pm 30^{\circ} \mathrm{C}$ (Bohlen et al. $1980 \mathrm{~b}$ ). In sum, barometry in the Adirondacks seems to give results which are independent of rock type and which vary smoothly across the terrane from about $6 \mathrm{~kb}$ in the Lowlands and southern Adirondacks to roughly $8 \mathrm{~kb}$ in the Highlands. The close agreement of several different barometers suggests that peak or close to peak regional $P$ has been retained.

$P$ in the Highlands calculated from reaction (9) ranges from 7.3 to $7.9 \mathrm{~kb}$ (with one exception) and compares well with the above constraints (Fig. 4). Results in lower $T$ areas, southeast and north of the Highlands, are 6.5 and $6.6 \mathrm{~kb}$ with a third assemblage giving a lower value of $5.6 \mathrm{~kb}$. These values are barely consistent with the $P$ maximum of $6.0 \pm 0.5 \mathrm{~kb}$ inferred from ubiquitous sillimanite. Two assemblages, in samples I87-4 and 233-1, give $P$ which seem anomalously low when compared with those from nearby assemblages. This may be due to the high $\mathrm{Fe}$ content of these two rocks (Table 2). One might expect activity models for solid solutions to lose accuracy as they are required to describe increasingly dilute phases.

$P$ calculated from reaction (8) seems to be systematically high by 1 to $2 \mathrm{~kb}$ (Fig. 3). Values ranging from 8.9 to $9.9 \mathrm{~kb}$ in the Highlands disagree with an estimate of $7.4 \pm 1.0 \mathrm{~kb}$ at Cascade Slide. Results of $9.5,8.8$ and $8.1 \mathrm{~kb}$ in lower $T$ areas are inconsistent with the $P$ maximum of $6.0 \pm 0.5 \mathrm{~kb}$ imposed by the presence of sillimanite. As with reaction (9), Fe-rich assemblages appear to give low values. The apparent systematic error in $P$ calculated from reaction (8) may be the result of imprecise activity models. The activities of diopside-hedenbergite and hercynite-spinel solid solutions in particular are not well constrained; the presence of both phases in reaction (8) may well contribute to inaccuracy in calculated $P$. Also, as mentioned above, reaction

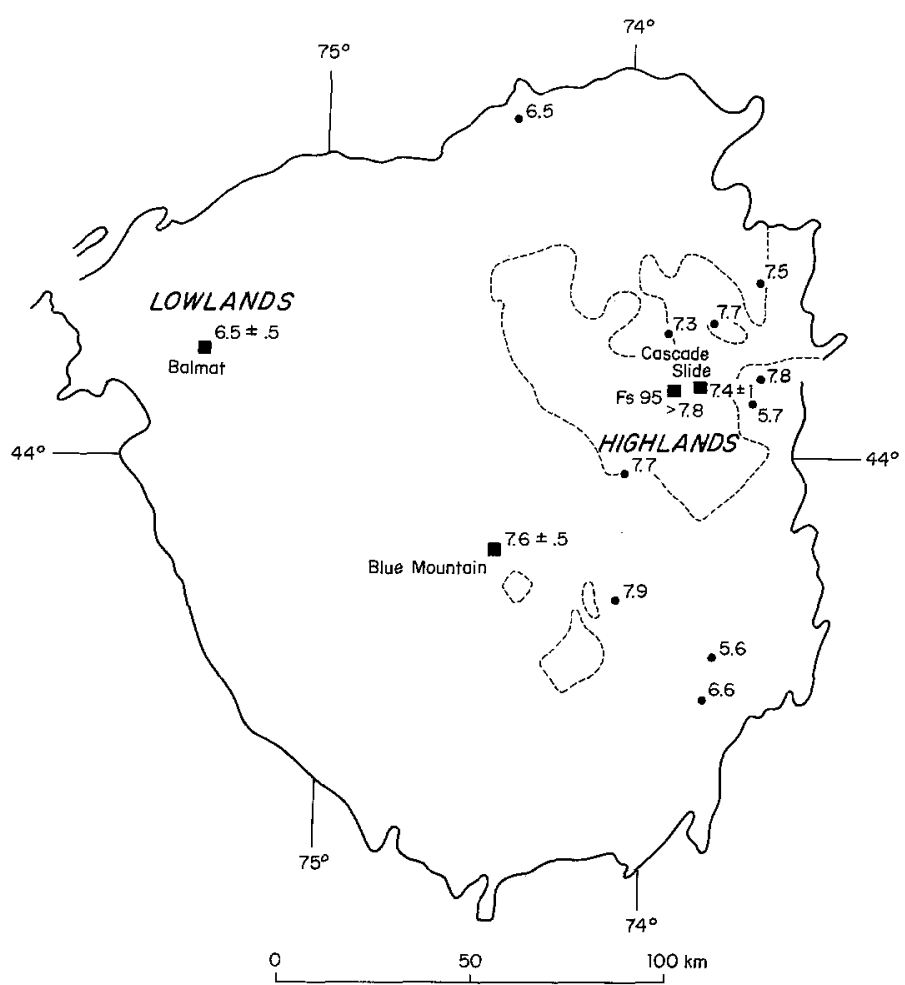

Fig. 4. Outline of Precambrian rocks in the Adirondacks. Symbols as in Fig. 3 except $\bullet$ which signifies metamorphic $P$ calculated using reaction (9)

(8) may be located here at erroneously high $P$ as a result of disorder in experimental spinel.

Whitney and McLelland (1973) and Whitney (1978) interpret coronal garnet in some Adirondack gabbros as retrograde. They suggest that these rocks retain no peak metamorphic information, only evidence of a retrograde path. Gabbros of this textural type are common in high-grade terranes (for example, Shand 1945; Friedman 1955, 1957; Murthy 1958; Martignole and Schrijver 1971; Griffin and Heier 1973; Whitney and McLelland 1973; Grieve and Gittins 1975; van Lamoen 1979). An isobaric cooling path at moderate to high $P$ is often invoked (for example, Martignole and Schrijver 1971; Griffin and Heier 1973; Whitney and McLelland 1973) to explain rimming relationships.

Whatever their mode of origin, the coronal minerals seem to have equilibrated chemically at or near what are inferred to be peak metamorphic conditions in the Adirondacks (Valley and Bohlen 1979). Inhomogeneity in coronal phases is very slight, on the order of routine microprobe uncertainty. For example, the maximum variation observed in garnets was $9 \%$ of the amount of an element present. There is no significant chemical zoning in any of the phases (Gasparik 1980, this report), contrary to what one might expect in rocks which texturally show partially completed reactions. Further, phases which occur in the same rock both in rimming relationships and as equant, apparent equilibrium phases, are essentially identical in composition. The two types of garnet differ by at most 2 or $3 \mathrm{~mol} \%$ pyrope or almandine (Table 2, sample AS-1), the two types of spinel by at most $5 \mathrm{~mol} \%$ hercynite (Table 2, samples SC-2 and W-2). McLelland and Whitney (1980a) report compositional variations in plagioclase related to spinel cloud- 
ing, but the magnitude of those variations does not appear large (about $5 \mathrm{~mol} \% \mathrm{An}$ ). Their effect on the phase equilibria is negligible. In addition, there is no $K_{\mathrm{D}}$-type evidence for strong $T$ gradients. The garnet-clinopyroxene $K_{\mathrm{D}}$ thermometer (Ellis and Green 1979) and the two-pyroxene thermometer (Wood and Banno 1973), both useful in granulites as semi-quantitative tools, are broadly consistent with inferred peak $T$ (Johnson et al. 1982). $P$ calculated (Table 4) using data from rocks showing coronal textures (AS-1, TL1, W-2, LP-2, LL-1, 233-1) are in close agreement with those calculated using data from more equant, recrystallized rocks (I87-1, SC-2, N-3, I87-4). In addition, these $P$ appear to be consistent with $P$ information retained by the numerous other Adirondack assemblages discussed above. We suggest that the coronal rocks have undergone a sweeping chemical reequilibration during metamorphism while preserving a reaction texture. What is unquestionably textural disequilibrium may be preserved as a result of low water fugacities in the rocks inhibiting recrystallization and annealing.

Limited data from the literature permit estimates of metamorphic $P$ in other high-grade terranes. Based on garnet reactions in the Fe-bearing system, Wood (1975) proposes $P$ of 10 to $13 \mathrm{~kb}$ at 800 to $860^{\circ} \mathrm{C}$ for three metagabbros with garnet $\left(\mathrm{Gr}_{20-29} \mathrm{Alm}_{47-56} \mathrm{Pp}_{21-32} \mathrm{Sp}_{1}\right)$ and plagioclase $\left(\mathrm{An}_{29-45}\right)$ from South Harris, Scotland. Reaction (9) suggests values of $7.9,8.2$ and $8.7 \mathrm{~kb}$ which, in the absence of olivine, represent $P$ minima. Berg (1977; written comm.) reports coexisting garnet $\left(\mathrm{Gr}_{3} \mathrm{Alm}_{85} \mathrm{Pp}_{10} \mathrm{Sp}_{2}\right)$, olivine $\left(\mathrm{FO}_{14}\right)$, plagioclase $\left(\mathrm{An}_{40}\right)$, hypersthene and quartz in a contact aureole of the Nain Complex, Labrador. In this very Fe-rich rock, garnet has been stabilized at quite low $P$. Berg (written comm.) now estimates that this rock equilibrated at $825^{\circ} \mathrm{C}$ and $2.5 \mathrm{~kb}$. Bohlen and Boettcher (1981) suggest a $P$ of $3.2 \mathrm{~kb}$ based on coexisting orthopyroxene, olivine and quartz. Calculations using reaction (9) give $0.9 \mathrm{~kb}$. This represents reasonably good agreement considering the extreme dilution of forsterite and $\mathrm{Gr}_{33} \mathrm{Pp}_{67}$ and the resulting large $P$ shift $(-9.2 \mathrm{~kb})$ of the reaction.

\section{Conclusions}

A $P-T-X$ calibration of garnet-forming reactions in silica-undersaturated systems has been developed using the best available experiments and thermodynamic data on reactant and product phases and on common solid solution series. This calibration has been field tested in the Adirondacks and shows acceptable agreement with other barometers indicating that Adirondack metamorphic conditions ranged from approximately $800^{\circ} \mathrm{C}$ and 7.0 to $8.0 \mathrm{~kb}$ in the Highlands to roughly $650^{\circ} \mathrm{C}$ and $6.5 \mathrm{~kb}$ in the margins of the terrane.

Garnet-forming reactions appear to be strongly affected by the solid solutions found in natural systems. Failure to account for these effects and uncritical application of experimental data generally lead to overestimates of $P$ in regionally metamorphosed granulites. Garnet is stable in the Nain Complex at $P$ as low as 2.5 (or 3.2) kb due to extreme dilution of forsterite and $\mathrm{Gr}_{33} \mathrm{Pp}_{67}$ with $\mathrm{Fe}$. In the Adirondacks, solid solutions may have stabilized garnet in silica-undersaturated gabbros at $P$ as low as $6.5 \mathrm{~kb}$. We conclude that garnet in silica-undersaturated gabbros in the Adirondacks may be a stable phase having equilibrated at peak metamorphic $P$ and $T$. A significantly retrograde origin for this phase is not required.

\section{Appendix I: Sample locations.}

I87-1 I87, 3.1 mi S of Elizabethtown exit, Elizabethtown Quad

SC-2 Walkersville Rd, $2.6 \mathrm{mi}$ S of Skerry, Santa Clara Quad

AS-1 South side of Jay Mtn, Au Sable Forks Quad

TL-1 Barton Mine pit, Gore Mtn, Thirteenth Lake Quad

N-3 West side of Pine Hill, Newcomb Quad

W-2 0.5 mi SE of Sugarloaf Mtn, Willsboro Quad

LP-2 South side of Clements Mtn, Lake Placid Quad

LL-1 Rt 418, 0.5 mi E of Thurman Sta, Lake Luzerne Quad

I87-4 I87, 8.3 mi S of Elizabethtown exit, Elizabethtown Quad

233-1 $0.7 \mathrm{mi}$ E of Forest Lake, North Creek Quad

Acknowledgements. The authors wish to thank Dr. S.R. Bohlen for assistance and constructive criticism throughout this project. The electron microbeam facilities at The University of Michigan are supervised by Prof. W.C. Bigelow of the Department of Metallurgy and Material Science. L.F. Allard, D.F. Blake, S. Krause and A.J. Mardinly gave valuable assistance in data collection. We thank Drs. S.S. Farrar for providing sample 233-1, J.H. Berg, J.G. Blencoe, M. Engi and V.J. Wall for unpublished data and V.J. Wall for suggestions. Drs. D.R. Peacor, S.K. Saxena and B.J. Wood are thanked for their reviews of the manuscript. Mr. Derwin Bell drafted the figures. This research was funded by National Science Foundation Grant No. EAR 78-23568 to EJE, a Sigma Xi Grant-in-Aid of Research to CAJ and the Scott Turner Fund of The University of Michigan.

\section{References}

Berg JH (1977) Dry granulite mineral assemblages in the contact aureoles of the Nain Complex, Labrador. Contrib Mineral Petrol $64: 33-52$

Birch F (1966) Compressibility; elastic constants. In: Clark SP, Jr (ed) Handbook of Physical Constants. Geol Soc Am Mem 97

Bohlen SR, Boettcher AL (1981) Experimental investigations and geological applications of orthopyroxene geobarometry. Am Mineral 66:951-964

Bohlen SR, Essene EJ (1978a) Igneous pyroxenes from metamorphosed anorthosite massifs. Contrib Mineral Petrol 65:433-442

Bohlen SR, Essene EJ (1978b) The significance of metamorphic fluorite in the Adirondacks. Geochim Cosmochim Acta 42:1669-1678

Bohlen SR, Essene EJ, Boettcher AL (1980a) Reinvestigation and application of olivine-quartz-orthopyroxene barometry. Earth Planet Sci Lett 47:1-10

Bohlen SR, Essene EJ, Hoffman KS (1980b) Update on feldspar and oxide thermometry in the Adirondack Mountains, New York. Geol Soc Am Bull, Part I, 91:110-113

Boone GM (1978) Kyanite in Adirondack Highlands sillimaniterich gneiss and $\mathrm{P}-\mathrm{T}$ estimates of metamorphism. Geol Soc Am Abstr with Program 10:34

Brown GM, Pinset RH, Coisy P (1980) The petrology of spinelperidotite xenoliths from the Massif Central, France. Am J Sci 280 A : 481-498

Brown PE, Essene EJ, Kelly WC (1978) Sphalerite geobarometry in the Balmat-Edwards district, New York. Am Mineral 63:250-257

Buddington AF (1939) Adirondack igneous rocks and their metamorphism. Geol Soc Am Mem 7

Carswell DA, Clarke DB, Mitchell RH (1979) The petrology and geochemistry of ultramafic nodules from Pipe 200, northern Lesotho. In: The Mantle Sample: Inclusions in Kimberlites and other Volcanics. Proc Second Int Kimb Conf, vol 2, AGU, pp 127-144

Cressey G, Schmid R, Wood BJ (1978) Thermodynamic properties 
of almandine-grossular solid solutions. Contrib Mineral Petrol $67: 397-404$

Ellis DJ, Green DH (1979) An experimental study of the effect of $\mathrm{Ca}$ upon garnet-clinopyroxene $\mathrm{Fe}-\mathrm{Mg}$ exchange equilibria. Contrib Mineral Petrol 71:13-22

Engi M (1980) The solid solution behavior of olivine in the temperature range from $500 \mathrm{~K}$ to $1,500 \mathrm{~K}$. Geol Soc Am Abstr with Program 12:421

Friedman GM (1955) Petrology of the Memesagamessing Lake norite mass, Ontario, Canada. Am J Sci 253:590-608

Friedman GM (1957) Structure and petrology of the Caribou Lake intrusive body, Ontario, Canada. Geol Soc Am Bull 68:1531-1564

Froese E, Gordon TM (1974) Activity coefficients of coexisting pyroxenes. Am Mineral 59:204-205

Ganguly J, Kennedy GC (1974) The energetics of natural garnet solid solution I. Mixing of the aluminosilicate end-members. Contrib Mineral Petrol 48:137-148

Gasparik T (1980) Geology of the Precambrian rocks between Elizabethtown and Mineville, eastern Adirondacks, New York. Geol Soc Am Bull, Part I, 91:78-88

Green DH, Ringwood AE (1967) An experimental investigation of the gabbro to eclogite transformation and its petrological applications. Geochim Cosmochim Acta 31:767-833

Grieve RAF, Gittins J (1975) Composition and formation of coronas in the Hadlington Gabbro, Ontario, Canada. Can J Earth Sci 12:289-299

Griffin WL, Heier KS (1973) Petrological implications of some corona structures. Lithos $6: 315-335$

Hafner S, Laves F (1961) Ordnung/unordnung und ultrarotabsorption III. Die systeme $\mathrm{MgAl}_{2} \mathrm{O}_{4}-\mathrm{Al}_{2} \mathrm{O}_{3}$ und $\mathrm{MgAl}_{2} \mathrm{O}_{4}-$ $\mathrm{LiAl}_{5} \mathrm{O}_{8} . \mathrm{Z}$ Kristallogr Mineral 115:321-330

Haselton HT, Westrum EF (1980) Low-temperature heat capacities of synthetic pyrope, grossular and pyrope ${ }_{60}$ grossular $_{40}$. Geochim Cosmochim Acta 44:701-709

Herzberg CT (1972) Stability fields of plagioclase- and spinel-lherzolite. In: Progress in Experimental Petrology. Natural Environment Research Council Publications, London, pp 145-148

Herzberg CT (1976) The plagioclase/spinel-lherzolite facies boundary: Its bearing on corona structure formation and tectonic history of the Norwegian Caledonides. In: Progress in Experimental Petrology. Natural Enviroument Research Council Publications, London, pp 233-235

Herzberg CT (1978a) The bearing of phase equilibria in simple and complex systems on the origin and evolution of some welldocumented garnet-websterites. Contrib Mineral Petrol $66: 375-382$

Herzberg CT (1978b) Pyroxene geothermometry and geobarometry: Experimental and thermodynamic evaluation of some subsolidus phase relations involving pyroxenes in the system $\mathrm{CaO}-\mathrm{MgO}-\mathrm{Al}_{2} \mathrm{O}_{3}-\mathrm{SiO}_{2}$. Geochim Cosmochim Acta 42:945-957

Herzberg CT, Chapman NA (1976) Clinopyroxene geothermometry of spinel-1herzolites. Am Mineral 61:626-637

Holdaway MJ (1971) Stability of andalusite and the aluminum silicate phase diagram. Am J Sci 271:97-131

Ito K, Kennedy GC (1971) An experimental study of the basaltgarnet granulite-eclogite transition. In: Heacock JG (ed) The Structure and Physical Properties of the Earth's Crust. AGU Mon 14:303-314

Jaffe HW, Robinson P, Tracy RJ (1978) Orthoferrosilite and other iron-rich pyroxenes in microperthite gneiss of the Mount Marcy area, Adirondack Mountains. Am Mineral 63:1116-1136

Jenkins DM, Newton RC (1979) Experimental determination of the spinel peridotite to garnet peridotite inversion at $900^{\circ} \mathrm{C}$ and $1,000^{\circ} \mathrm{C}$ in the system $\mathrm{CaO}-\mathrm{MgO}-\mathrm{Al}_{2} \mathrm{O}_{3}-\mathrm{SiO}_{2}$ and at $900^{\circ} \mathrm{C}$ with natural garnet and olivine. Contrib Mineral Petrol $68: 407-419$

Johnson CA, Bohlen SR, Essene EJ (1982) An evaluation of garnet-clinopyroxene geothermometry in granulites. Submitted to Lithos
Krupka KM, Kerrick DM, Robie RA (1979) Heat capacities of synthetic orthoenstatite and natural anthophyllite from 5 to $1,000 \mathrm{~K}$. EOS Trans AGU 60:405

Krupka KM, Kerrick DM, Robie RA (1980) Heat capacities from 5 to $1,000 \mathrm{~K}$ for natural diopside, wollastonite and orthoenstatite. EOS Trans AGU 61:407

Kushiro I, Yoder HS, Jr (1966) Anorthite-forsterite and anorthiteenstatite reactions and their bearing on the basalt-eclogite transition. J Petrol 7:337-362

Lindsley DH, Dixon S (1976) Diopside-enstatite equilibria at $850^{\circ} \mathrm{C}$ to $1,400^{\circ} \mathrm{C}, 5$ to $35 \mathrm{~kb}$. Am J Sci $276: 1285-1301$

MacGregor ID (1970) The effect of $\mathrm{CaO}, \mathrm{Cr}_{2} \mathrm{O}_{3}, \mathrm{Fe}_{2} \mathrm{O}_{3}$ and $\mathrm{Al}_{2} \mathrm{O}_{3}$ on the stability of spinel and garnet peridotites. Phys Earth Planet Interior 3:372-377

Martignole J, Schrijver K (1971) Association of (hornblende-) garnet-clinopyroxene "subfacies" of metamorphism and anorthosite masses. Can J Earth Sci 8:698-704

McLelland JM, Whitney PR (1980a) Compositional controls on spinel clouding and garnet formation in plagioclase of olivine metagabbros, Adirondack Mountains, New York. Contrib Mineral Petrol 73:243-251

McLelland JM, Whitney PR (1980 b) A generalized garnet-forming reaction for metaigneous rocks in the Adirondacks. Contrib Mineral Petrol 72:111-122

Murthy MVN (1958) Coronites from India and their bearing on the origin of coronas. Geol Soc Am Bull 68:23-38

Navrotsky A, Kleppa OJ (1967) The thermodynamics of cation distributions in simple spinels. $\mathbf{J}$ Inorg Nucl Chem 29:2701- 2714

Newton RC (1966) Kyanite-sillimanite equilibrium at $750^{\circ} \mathrm{C}$. Science 151:1222-1225

Obata $\mathrm{M}(1976)$ The solubility of $\mathrm{Al}_{2} \mathrm{O}_{3}$ in orthopyroxenes in spinel and plagioclase peridotites and spinel pyroxenites. Am Mineral 61:804-816

O'Hara MJ, Richardson SW, Wilson G (1971) Garnet peridotite stability and occurrence in crust and mantle. Contrib Mineral Petrol 32:48-68

O'Neill HStC (1981) The transition between spinel lherzolite and garnet 1herzolite, and its use as a geobarometer. Contrib Mineral Petrol 77:185-194

Orville PM (1972) Plagioclase cation exchange equilibria with aqueous solution: results at $700^{\circ} \mathrm{C}$ and 2,000 bar in the presence of quartz. Am J Sci 272:234-272

Perkins D, III (1979) Application of new thermodynamic data to mineral equilibria. Univ of Michigan $\mathrm{PhD}$ Dissertation

Presnall DC (1976) Alumina content of enstatite as a geobarometer for plagioclase and spinel Iherzolites. Am Mineral 61:582588

Richardson SW, Bell PM, Gilbert MC (1968) Kyanite-sillimanite equilibrium between $700^{\circ} \mathrm{C}$ and $1,500^{\circ} \mathrm{C}$. Am J Sci 266:513-541

Ringwood AE, Green DH (1964) Experimental investigations bearing on the nature of the Mohorovicic discontinuity. Nature 201:566-567

Ringwood AE, Green DH (1966) An experimental investigation of the gabbro-eclogite transformation and some geophysical implications. Tectonophysics 3:383-427

Robie RA, Hemingway BS, Fisher JR (1978) Thermodynamic properties of minerals and related substances at $298.15 \mathrm{~K}$ and 1 bar $\left(10^{5}\right.$ Pascals $)$ pressure and at higher temperatures. Bull US Geol Surv 1452

Rucklidge JC, Gasparrini EL (1969) Specifications of a complete program for processing electron microprobe data: EMPADR VII. Dept. of Geology, Univ of Toronto, unpubl circular

Sack RO (1980a) Adirondack mafic granulites and a model lower crust. Geol Soc Am Bull, Part II, 91:349-442

Sack RO (1980b) Some constraints on the thermodynamic mixing properties of $\mathrm{Fe}-\mathrm{Mg}$ orthopyroxenes and olivines. Contrib Mineral Petrol 71:257-269

Saxena SK (1973) Thermodynamics of Rock-forming Crystalline Solutions. Springer-Verlag, New York 
Schmid R, Wood BJ (1976) Phase relationships in granulitic metapelites from the Ivrea-Verbano Zone (Northern Italy). Contrib Mineral Petrol 54:255-279

Seil MK, Blencoe JG (1979) Activity-composition relations of $\mathrm{NaAlSi}{ }_{3} \mathrm{O}_{8}-\mathrm{CaAl}_{2} \mathrm{Si}_{2} \mathrm{O}_{8}$ feldspars at $2 \mathrm{~kb}, 600-800^{\circ} \mathrm{C}$. Geol Soc Am Abstr with Program 11:513

Shand SJ (1945) Coronas and coronites. Geol Soc Am Bull $56: 247-266$

Shannon RD (1976) Revised effective ionic radii and systematic studies of interatomic distances in halides and chalcogenides. Acta Crystallogr Sect A 32:751-767

Skinner BJ (1966) Thermal expansion. In: Clark SP, Jr (ed) Handbook of Physical Constants. Geol Soc Am Mem 97

Stoll E, Fischer P, Halg W, Maier G (1964) Redetermination of the cation distribution of spinel $\left(\mathrm{MgAl}_{2} \mathrm{O}_{4}\right)$ by means of neutron diffraction. J Phys 25:447-448

Valley JW, Bohlen SR (1979) A petrogenetic grid for Adirondack metamorphism. Geol Soc Am Abstr with Program 11:57

Valley JW, Essene EJ (1980a) Akermanite in the Cascade Slide xenolith and its significance for regional metamorphism in the Adirondacks. Contrib Mineral Petrol 74:143-152

Valley JW, Essene EJ (1980 b) Calc-silicate reactions in Adirondack. marbles: the role of fluids and solid solutions. Geol Soc Am Bull, Part II, $91: 720-815$
Valley JW, O'Neil JR $(1981){ }^{13} \mathrm{C} /{ }^{12} \mathrm{C}$ exchange between calcite and graphite: a possible thermometer in Grenville marbles. Geochim Cosmochim Acta 45:411-419

Van Lamoen H (1979) Coronas in olivine gabbros and iron ores from Susimäki and Riuttamaa, Finland. Contrib Mineral Petrol $68: 259-268$

Whitney PR (1972) Spinel inclusions in plagioclase of metagabbros from the Adirondack Highlands. Am Mineral 57:1429-1436

Whitney PR (1978) The significance of garnet "isograds" in granulite facies rocks of the Adirondacks. In: Metamorphism in the Canadian Shield. Geol Surv Can Pap 78-10

Whitney PR, McLelland JM (1973) Origin of coronas in metagabbros of the Adirondack Mts., N.Y. Contrib Mineral Petrol $39: 81-98$

Wood BJ (1975) The influence of pressure, temperature and bulk composition of the appearance of garnet in orthogneisses an example from South Harris, Scotland. Earth Planet Sci Lett 26:299-311

Wood BJ, Banno S (1973) Garnet-orthopyroxene and orthopyroxene-clinopyroxene relationships in simple and complex systems. Contrib Mineral Petrol 42:109-124

Received August 7, 1981;

Accepted in revised form September 15, 1982 